\title{
Antifungal Activity of Spearmint and Peppermint Essential Oils against Macrophomina Root Rot of Cotton \\ Fathia S. El-Shoraky ${ }^{1}$ and A. Y. Shala ${ }^{2}$ \\ ${ }^{1}$ Institute of Plant Pathology, Agricultural Research Center, Giza, Egypt \\ Email: felshoraki@yahoo.com \\ ${ }^{2}$ Medicinal and Aromatic Plants Research Department, Horticulture Research Institute. Agricultural Research Center, Giza, Egypt. Email: awad.shala@yahoo.com
}

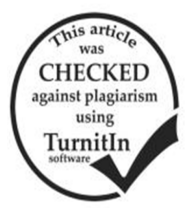

ABSTRACT

Essential oils as natural antifungal substances one of the alternative methods for plant disease control. The present study was conducted during 2015 and 2016 to investigate the antifungal activity and oil constituents of volatile oils from spearmint (Mentha viridis L.) and peppermint (Mentha piperita L.) against cotton root rot pathogen (Macrophomina phaseolina). Gas chromatographic analysis revealed that spearmint volatile oil was constituted by carvone $(60.16 \%)$ as a major component followed by 1,8 cineole $(8.67 \%)$, limonene $(7.40 \%)$, dihydro carvone $(5.86 \%), \beta$ - ocimene $(4.29 \%)$ and pulegone $(3.23 \%)$. While peppermint volatile oil was rich in menthone (46.52\%), menthol (25.88\%), limonene (7.72\%) menthyl acetate $(3.90 \%)$, iso menthol $(2.10 \%)$ and sabinene $(2.03 \%)$. Both essential oils with different concentrations were evaluated in vitro against three fungus isolates. The two tested oils exhibited 89.55 inhibition percent for the crude oils, against all the tested fungal isolates. Moreover, it was noticed that as oil concentrations decreased, the inhibitory effect also decreased. At the same time, a highly significant effect of oils at all concentrations was observed during sclerotial formation (number and size). The use of essential oils as seed treatment exhibited a highly significant reduction in disease incidence of cotton which has been artificially infested with root rot pathogen, compared to fungicide and untreated control treatments under the greenhouse conditions. This reduction was calculated to be between 4.56 and $100 \%$ compared with a $26.67 \%$ reduction with the utilization of Topsin $\mathrm{M}$ treatment at the pre-emergence stage. At the post-emergence stage, all applied treatments were able to decrease the percentage of root-rot incidence. Reduction ranged between 66.67 and $100 \%$ over the untreated control. Reduction in disease incidence was reflected in a survival plants increase of $34.62-96.17 \%$ and $73.09-126.9 \%$ for spearmint and peppermint volatile oils, receptively. Results in the current study demonstrated, that application of peppermint essential oils has an observer influence on the plant growth (plant height), which differ significantly from this of spearmint oil.

Keywords: spearmint; peppermint; essential oil; cotton; Macrophomina phaseolina

\section{INTRODUCTION}

Macrophomina phaseolina (Tassi) Goid is one of the most important soil borne pathogens, has a wide host range and infected over 500 plant species in more than 100 plant families around the world(Khan, 2007). The fungus responsible for causing a major disease of cotton (Gossypium barbadense) and has been cause severe losses from seedling to maturity of cotton. Despite its wide host range, the genus Macrophomina includes only one species, $M$. phaseolina. Variation in morphology and virulence between isolates of $M$. phaseolina was described as polyphagous and cosmopolitan fungus which attack several species of cultivated plants, comprising sorghum, soybean, cotton, and corn (Su et al., 2001).

Due to the development of resistance to the synthetic fungicide and accumulation of residues, the utilization of natural products is deemed one of the better substitutes for fungal disease management (Gujar and Talwankar, 2012). Many scholars are trying to find effective natural products for controlling plant diseases replacing synthetic pesticides (Kim et al., 2005). Various plant extracts have been reported as a source of biopesticide because it's inhibited the growth of plant pathogens and reduced the hazard impacts to human health and the environment. Various medicinal plants which have antifungal properties can also be employed as a source of plant bio pesticides (Aslam et al., 2010). Plant biopesticides are cheap, locally available, nontoxic, and easily degradable (Hadizadeh et al., 2009). Furthermore, its display structural diversity, complexity and rarely include halogenated atoms. These can act completely as pesticides (Neerman, 2003).

Lamiaceae family involves more than 4000 species in 200 genera. Numerous species in lamiaceae family are medicinal plants that apply in human disease remedy as well as food in a raw and cooked form (Dhifi et al., 2011). Mentha piperita is a perennial herbaceous plant belonging to the family Lamiaceae. It is indigenous of the Mediterranean region. Peppermint oil is the greatest popular and extensively utilized essential oil in food, pharmaceutical and cosmetic industries (Baser 1993). The biological activity of peppermint essential oil against fungi and bacteria have been formerly reported by Jirovetz et al., (2007) and Moghaddam et al., (2013) Furthermore, the antifungal and antibacterial activities of the Mentha viridis volatile oil components have been defined in the previous literature (Singh, et al., 1994 and Mkaddem et al., 2009).

The hazardous influences of synthetic chemicals fungicides result in a growing attention in exploiting alternative and harmless treatments is a great challenge. Previous reports elucidated the antifungal activity of essential oils involving lemongrass, citronella, clove, peppermint, thyme and oregano oils against various fungal species (Viuda-Martos et al. 2007). Antifungal activities of specific essential oils were noticed effective against Rhizoctonia solani, Fusarium moniliforme and Sclerotinia sclerotiorum (Muller et al., 1995), F. oxysporum (Bowers and Locke, 2000), and F. solani, $R$. solani, Pythium ultimum and Colletotrichum lindemuthianum (Zambonelli et al., 1996). The mechanism of action of these compounds against fungi may be correlated to their capability to dissolve or disrupt the integrity of cell walls and membranes (Isman and Machial, 2006). Also, essential oils from eleven medicinal plants were effective in controlling several soilborne cotton pathogenic fungi (Fusarium poae, F. oxysporum, F. moniliforme, F. solani, Rhizoctonia solani, Macrophomina phaseolina, and Sclerotium rolfsii) under the greenhouse and field conditions (El-Shoraky, 2016). Moreover, essential oils of thyme and spearmint 
diminished in vitro growth of the pathogenic fungi, $R$. Solani, Pythium ultimum var. ultimum, Fusarium solani and Colletotrichum lindemuthianum (Zambonelli et al., 1996). New biocides-based methods have advanced by using formulations of essential oils. These formulations, obtained from fennel, peppermint, caraway, oregano, rosemary, and ginger, are emulsified with diverse fixed oils (sesame, olive, cotton and soybean oils) to be operated as a carrier (Bowers \& Locke, 2000 and Mario et al., 2002). Formulations derived from ginger has been utilized in treating black rot caused by Alternaria alternata in tomato fruits (Helal \& Abdeldaiem, 2009).

In relation to $M$. phaseolina chemical control, there are no fungicides registered for this pathogen. Thus, it is necessary to evaluate natural alternatives as a fungicide and their efficiency for controlling it. So, the present study aimed to evaluate the antifungal potential of Mentha viridis L. and Mentha piperita L. essential oils against three isolates of $M$. phaseolina and to determine both essential oil constituents. At the same time, to assess the essential oils effectiveness as cotton seed treatments in controlling Macrophomina root rot in cotton.

\section{MATERIALS AND METHODS}

\section{Essential oils extraction and oil constituents}

The tested plants were acquired from Medicinal and Aromatic Plants Research Department, Horticulture Research Institute, Agriculture Research Center (ARC), Ministry of Agriculture, Egypt. Fresh herb of spearmint (Mentha viridis) and peppermint (Mentha piperita L.) Family Labiatae. These plants were chosen on the basis of earlier knowledge on their antifungal activities (Singh, et al., 1994 and Moghaddam et al., 2013). The essential oils were extracted by steam distillation using Clevenger type apparatus for 3 hours. The extracted oils were dried over anhydrous sodium sulfate. Gas Chromatographic analysis (GC) was determined for spearmint and peppermint essential oils at Medicinal and Aromatic Plants Research Department lab., Horticulture Research Institute, Agriculture Research Center, Giza, Egypt which were investigated by DsChrom 6200 Gas Chromatograph prepared with a flame ionization detector for separation of volatile oil constituents. The analysis circumstances were as follows: The chromatograph apparatus was installed with capillary column BPX-5, 5\% phenyl (equiv.) polysillphenylene-siloxane $30 \mathrm{~m}$ x $0.25 \mathrm{mmID} \times 0.25 \mu \mathrm{m}$ film. Temperature program ramp increase with a rate of 10 $\mathrm{C}^{\circ} /$ min from 70 to $200 \mathrm{C}^{\mathrm{o}}$. Flow rates of gases were nitrogen at $1 \mathrm{ml} / \mathrm{min}$, hydrogen at $30 \mathrm{ml} / \mathrm{min}$ and 330 $\mathrm{ml} / \mathrm{min}$ for air. Detector and injector temperatures were $300 \mathrm{C}^{\mathrm{o}}$ and $250 \mathrm{C}^{\mathrm{o}}$, respectively. The obtained chromatogram and report of GC analysis were analyzed to calculate the percentage of essential oils main components. The essential oils were then evaluated for antifungal activity (El-Shoraky\& Rashed, 2012).

\section{In vitro antagonists against $M$. phaseolina:}

Paper disc plate method (Loo et al., 1945) was used. Circular disc (5 mm dia.) of Whatman filter (No. 1) were cut and after dipping in different oils were located 1 $\mathrm{cm}$ inward from the periphery of Petri dishes at four equidistance places, having in the center the inoculum of the pathogen (M. phaseolina). Then, a $5 \mathrm{~mm}$ plug taken from 7 days old culture of the test fungus was placed on the center of PDA medium in a Petri dish and sealed with parafilm, plates were incubated at $25+3 \mathrm{C}^{\circ}$ for 5 days. At the completion of the incubation period, the linear growth of the mycelium was measured. Radial growth of $M$. phaseolina was recorded and the inhibition percentage was calculated using the following formula:

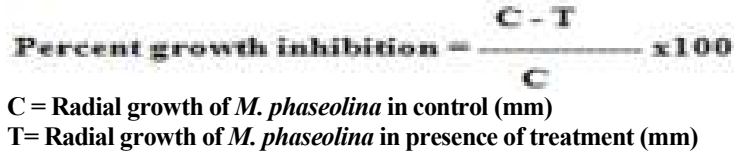

Based on the preliminary screening results the selected essential oils were prepared in paraffin oil and four doses viz., 1:1, 1:2, 1:3 and 1:4 (crude oil: paraffin oil) and applied on Whatman no. 1 filter papers ( $5 \mathrm{~mm}$ diameter), control papers were treated with paraffin oil only, another one was treated with Topsin $\mathrm{M}$ fungicide (Thiophenat methyl $70 \%$ ). The antifungal activity of essential oil was evaluated on the mycelia growth of $M$. phaseolina according to Boyraz and Ozcan (2006). Five-millimeter mycelia discs taken from the borders of a 7 days old culture were located in the middle of a (PDA) plate. Circular disc (5 mm dia.) of Whatman filter (No. 1) were cut and after dipping in different oils were placed $1 \mathrm{~cm}$ inward from the periphery of Petri dishes at four equidistance places, having in the center the inoculum of the pathogen (M. phaseolina). The Petri plates were sealed with parafilm and incubated at $24 \mathrm{C}^{\circ}$ for 5 days (Arya, et al., 2017).

\section{Sclerotial formations:}

The number and size of fungus sclerotia were counted in fungal culture suspensions under the microscope (at low power 10X). The fungal culture suspension was prepared by vigorously shaking the $5 \mathrm{~mm}$ mycelial disc of the fungus in $5 \mathrm{ml}$ (FAA) (Parmar et al., 2017).

In vivo experiments (pot experiments):

The present study was conducted at Cotton Pathology Department, Sakha Agric. Res. St. Seeds of a local cotton variety cv. Giza 96 were treated with different concentrations of the tested oils. From the preliminary trial, these concentrations hadn't harmful impacts on seeds germination. For comparison, some seeds were treated with Topsin M fungicide at the recommended dose $(3 \mathrm{~g} / \mathrm{kg}$ seeds). Greenhouse experiments have been performed to specify the efficiency of plant essential oils as a seed treatment to manage cotton root rot (caused by Macrophomina phaseolina). The potting mixture (soil) infested with $M$. phaseolina was used. In this experiment three agent's viz., two essential oils (spearmint and peppermint) and one fungicide (Topspin M) were used individually for seed treatment. Essential oils were used at $1 \mathrm{ml} \mathrm{kg}^{-1}$ seed while fungicide was used at $3 \mathrm{~g} / \mathrm{kg}$ seed. In case of control, seeds were sown in Macrophomina inoculated soil without any agents.

Preparation of fungal inoculum and soil infestation: Substrate for the growth of each isolate of M. phaseolina, was prepared by used autoclaved sorghum medium $(50 \mathrm{~g}$ of sorghum grains and $40 \mathrm{ml}$ of tap water) in $500 \mathrm{ml}$ glass bottles. Every bottle was inoculated with five discs $(0.5 \mathrm{~cm}$ in diameter) of the 5-day-old culture of fungus. Bottles were incubated at $25 \pm 1 \mathrm{C}^{\mathrm{o}}$ for 15 days. The inoculums which used for soil infestation was a mixture of equal amounts $(\mathrm{w} / \mathrm{w})$ of 3 isolates. 5\% formalin solution was used for soil and pots sterilizing for $15 \mathrm{~min}$. Sterilized soil 
was covered with a polyethylene sheet for 7 days to maintain the gas then left to dry for 2 weeks till all formaldehyde traces were disappeared. Inoculum was added at a rate of $3 \%(\mathrm{w} / \mathrm{w})$ and mixed carefully with the soil one week prior planting. The infested soil was dispensed in diameter $25 \mathrm{~cm}$ plastic pots and these were planted with treated seeds (10 seeds/pot) and kept in the greenhouse. Pre- and post-emergence damping- off were registered after 15 and 45 days from planting.

\section{Statistical analyses:}

Statistical analyses were performed using Assistat7.7 beta software for windows (Silva \& Azevedo, 2009.). A complete randomized design was used in these experiments. The collected data was statistically analyzed by Duncan's Multiple Range Test for comparing means.

\section{RESULTS}

Gas chromatographic analysis for spearmint essential oil (Chromatogram 1) revealed the presence of 15 components of which 11 components of them were

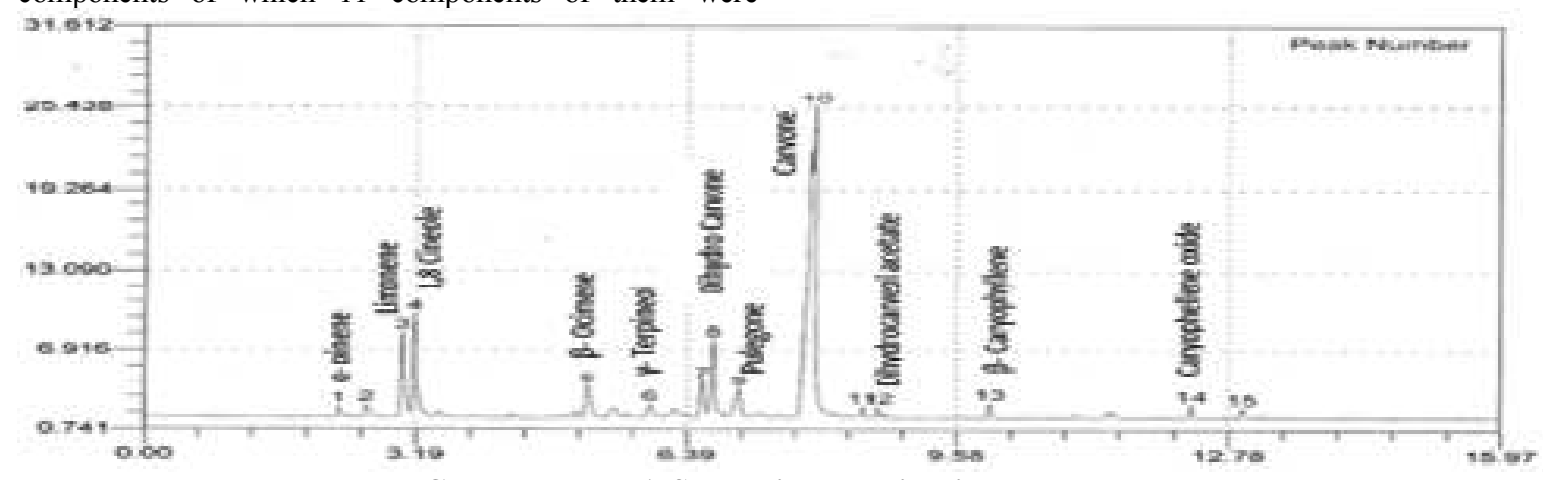

Chromatogram 1. Spearmint essential oil components

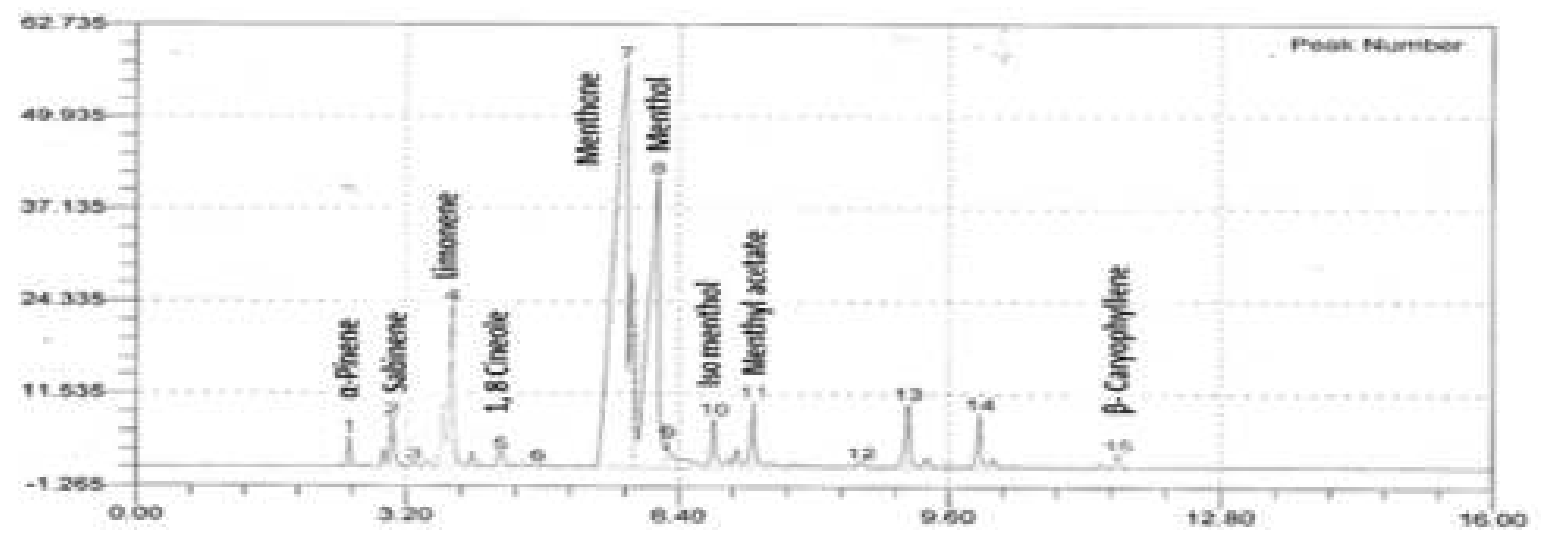

Chromatogram 2. Peppermint essential oil components

\section{Antifungal activity}

The antifungal activity of two essential oils (spearmint and peppermint) against mycelial growth of three isolates of Macrophomina phaseolina is displayed in (Table1). Statistical analysis $(\mathrm{p}=0.05)$ showed that both essential tested oils had antifungal activity against $M$. phaseolina. The obtained results showed that all concentrations of tested oils gave a reduction of fungus growth which was found significantly superior over or equal of the check fungicide. However, the two tested oils showed more than 88 percent inhibition in crude oils against all the tested fungal isolates. It was additionally detected that when concentrations of oil reduced, the inhibitory effect also reduced. identified by the retention times obtained from pure reference compounds. The identified components were $\alpha$ pinene $(0.55 \%)$, limonene $(7.40 \%), 1,8$ cineole $(8.67 \%)$, $\beta$ - ocimene $(4.29 \%), \gamma$ - terpineol $(1.23 \%)$, dihydro carvone $(5.86 \%)$, pulegone $(3.23 \%)$, carvone $(60.16 \%)$, dihydrocarveol acetate $(0.93 \%), \beta$ - caryophyllene $(0.95 \%)$ , caryophyllene oxide $(0.88 \%)$ and the rest of numbers are unknown these results were in accordance with Baser, (1993) and Mkaddem et al., (2009). While chromatographic analysis for peppermint essential oil revealed the presence of 15 components of which 9 components of them were identified (Chromatogram 2). The identified components were $\alpha$-pinene $(0.80 \%)$, sabinene $(2.03 \%)$, limonene $(7.72 \%), 1,8$ cineole $(0.83 \%)$, menthone $(46.52 \%)$, menthol ( $25.88 \%)$, iso menthol $(2.10 \%)$, menthyl acetate $(3.90 \%)$ and $\beta$ caryophyllene $(0.71 \%)$, whereas the rest of numbers are unknown these results were in harmony with the previous studiesJirovetz et al., (2007) and Moghaddam et al., (2013) 
Fathia S. El-Shoraky and A. Y. Shala

Table 1. The antifungal activity of two essential oils (spearmint and peppermint) against three Macrophomina phaseolina isolates (cotton root rot pathogen)

\begin{tabular}{|c|c|c|c|c|c|c|c|c|c|c|}
\hline \multirow{2}{*}{ Oils } & \multirow{2}{*}{\multicolumn{2}{|c|}{ Isolates }} & \multicolumn{6}{|c|}{ Oil concentrations ( $v: v)$} & & \\
\hline & & & Crude & $1: 1$ & $1: 2$ & $1: 3$ & $1: 4$ & $\mathbf{0}$ & & \\
\hline \multirow{8}{*}{ Spearmint } & \multirow{3}{*}{ M1 } & Linear & 0.47 & 0.70 & 0.70 & 0.83 & 1.00 & 4.50 & 1.10 & 4.50 \\
\hline & & growth & $\mathrm{C}$ & $\mathrm{BC}$ & $\mathrm{BC}$ & $\mathrm{BC}$ & $\mathrm{C}$ & A & B & A \\
\hline & & $\operatorname{In} \%{ }^{A}$ & 89.56 & 84.44 & 84.44 & 81.56 & 77.78 & 0.0 & 75.56 & -- \\
\hline & \multirow{3}{*}{ M2 } & Linear & 0.53 & 0.97 & 1.40 & 1.80 & 1.97 & 3.63 & 0.60 & 4.50 \\
\hline & & growth & $\mathrm{E}$ & $\mathrm{DE}$ & CD & $\mathrm{C}$ & $\mathrm{C}$ & B & $\mathrm{E}$ & A \\
\hline & & In $\%$ & 88.22 & 78.44 & 68.89 & 60.00 & 56.22 & 19.33 & 86.67 & -- \\
\hline & \multirow[b]{2}{*}{ M3 } & Linear & 0.47 & 1.20 & 1.50 & 1.70 & 1.93 & 3.73 & 0.93 & 4.50 \\
\hline & & $\begin{array}{l}\text { growth } \\
\text { In } \%\end{array}$ & $\begin{array}{c}\mathrm{F} \\
89.56\end{array}$ & $\begin{array}{c}\mathrm{DE} \\
73.33\end{array}$ & $\begin{array}{l}\text { CDE } \\
66.67\end{array}$ & $\begin{array}{l}\text { CD } \\
62.22\end{array}$ & $\begin{array}{c}\mathrm{C} \\
57.11\end{array}$ & B & $\begin{array}{c}\mathrm{EF} \\
79.33\end{array}$ & A \\
\hline \multirow{9}{*}{ Peppermint } & \multirow{3}{*}{ M1 } & Linear & 0.47 & 0.53 & 0.53 & 0.60 & 0.63 & 4.50 & 1.10 & 4.50 \\
\hline & & growth & $\mathrm{C}$ & $\mathrm{BC}$ & $\mathrm{BC}$ & $\mathrm{BC}$ & $\mathrm{BC}$ & A & B & A \\
\hline & & $\operatorname{In} \%$ & 89.56 & 88.22 & 88.22 & 86.67 & 86.00 & 0.00 & 75.55 & -- \\
\hline & \multirow{3}{*}{ M2 } & Linear & 0.47 & 0.57 & 0.73 & 0.83 & 0.87 & 3.57 & 0.60 & 4.50 \\
\hline & & growth & $\mathrm{C}$ & C & C & C & C & B & C & A \\
\hline & & $\operatorname{In} \%$ & 89.56 & 87.33 & 83.78 & 81.56 & 80.67 & 20.67 & 86.67 & -- \\
\hline & \multirow{3}{*}{ M3 } & Linear & 0.47 & 1.50 & 1.63 & 1.83 & 1.97 & 4.50 & 0.93 & 4.50 \\
\hline & & growth. & D & $\mathrm{BC}$ & B & B & B & A & $\mathrm{CD}$ & A \\
\hline & & $\operatorname{In} \%$ & 89.56 & 66.67 & 63.78 & 59.33 & 56.22 & 0.00 & 79.33 & -- \\
\hline \multirow{2}{*}{\multicolumn{3}{|c|}{$\begin{array}{l}\text { Mean of Linear } \\
\text { growth }\end{array}$}} & 0.48 & 0.91 & 1.08 & 1.27 & 1.39 & 4.07 & 0.88 & 4.50 \\
\hline & & & $\mathrm{f}$ & $\mathrm{e}$ & de & $\mathrm{cd}$ & $\mathrm{c}$ & $\mathrm{b}$ & $\mathrm{e}$ & $\mathrm{a}$ \\
\hline \multicolumn{11}{|c|}{$\begin{array}{l}\text { *mean values within rows followed by the same letter are not significantly different at } p<0.05 \\
\text { A inhibition percent in fungal growth under different treatments used, calculated relative to fungal growth in untreated control } \\
{ }^{B} \text { Concentrations of essential oils were calculated as (v: v) to the carrier oil }\end{array}$} \\
\hline \multicolumn{8}{|c|}{$\begin{array}{l}\text { Table 2. Analysis of variance of interactions between isolates of Macrophomina } \\
\text { different concentrations in vitro }\end{array}$} & \multicolumn{3}{|c|}{ phaseolina and essential oils } \\
\hline \multicolumn{3}{|c|}{ Parameters and Source of variation } & & $\overline{\mathrm{DF}}$ & & SS & & MS & & $\mathbf{F}$ \\
\hline \multicolumn{3}{|c|}{ Sclerotial number } & & & & & & & \multirow{2}{*}{\multicolumn{2}{|c|}{$1175.0483 * *$}} \\
\hline \multicolumn{3}{|c|}{ Isolates (a) } & & 2 & & 59.89575 & & 29.94788 & & \\
\hline Error-a & & & & 6 & & 0.15292 & & 0.02549 & & \\
\hline Oils (b) & & & & 1 & & 1.11446 & & 1.11446 & & $4597 * *$ \\
\hline Int. $\mathrm{a} \times \mathrm{b}$ & & & & 2 & & 1.21798 & & 0.60899 & & $1879 * *$ \\
\hline Error-b & & & & 6 & & 0.01682 & & 0.00280 & & \\
\hline Concentratic & & & & 6 & & 313.1977 & & 52.19962 & 220 & $.7848 * *$ \\
\hline Int. a x c & & & & 12 & & 15.81619 & & 1.31802 & & $7214 * *$ \\
\hline Int. b x c & & & & 6 & & 5.31679 & & 0.88613 & & $2960 * *$ \\
\hline Int. $\mathrm{a} \times \mathrm{b} \times \mathrm{c}$ & & & & 12 & & 5.30286 & & 0.44190 & & $6577 * *$ \\
\hline Error-c & & & & 72 & & 0.17046 & & 0.00237 & & \\
\hline Sclrtotial siz & & & & & & & & & & \\
\hline Isolates (a) & & & & 2 & & 0.12968 & & 0.06484 & & $000 \mathrm{~ns}$ \\
\hline Error-a & & & & 6 & & 0.10238 & & 0.01706 & & \\
\hline oils (b) & & & & 1 & & 0.02032 & & 0.02032 & & $245 \mathrm{~ns}$ \\
\hline Int. $\mathrm{a}$ x b & & & & 2 & & 0.69063 & & 0.34532 & & $7959 * *$ \\
\hline Error-b & & & & 6 & & 0.02333 & & 0.00389 & & \\
\hline Concentratio & & & & 6 & & 4.20762 & & 0.70127 & & $8824 * *$ \\
\hline Int. a x c & & & & 12 & & 0.09810 & & 0.00817 & & $294 * *$ \\
\hline Int. b x c & & & & 6 & & 0.10190 & & 0.01698 & & $2941 * *$ \\
\hline Int. $\mathrm{a} \times \mathrm{Tb} \mathrm{x}$ & & & & 12 & & 0.34381 & & 0.02865 & & $6176 * *$ \\
\hline Error-c & & & & 72 & & 0.19429 & & 0.00270 & & \\
\hline
\end{tabular}

** Significant at a level of $1 \%$ of probability $(p<.01)$

* Significant at a level of $5 \%$ of probability $(.01=<p<.05)$

ns Non-significant $(p>=.05)$

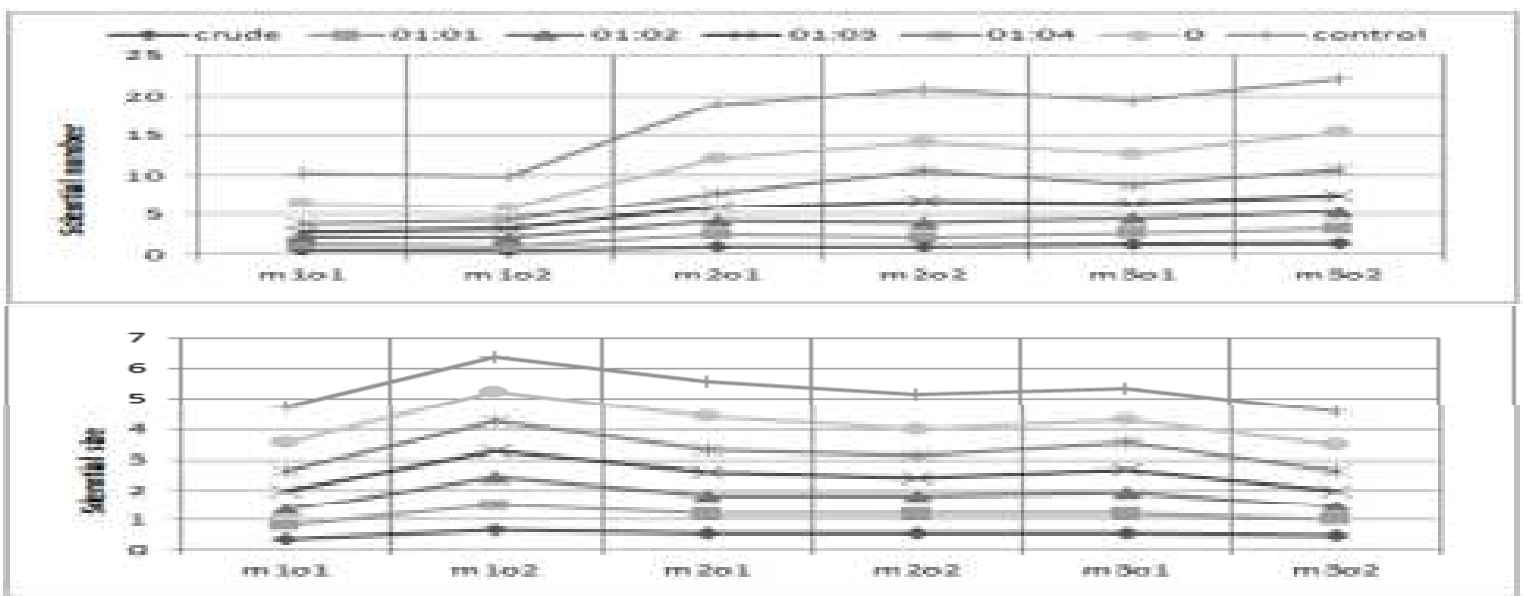

Fig .1. Effect of two essential oils \{spearmint (o1) and peppermint (02)\} at different concentrations on sclerotial formation (number and size $\mu \mathrm{m})$ of three Macrophomina phaseolina isolates $(\mathrm{m} 1-\mathrm{m} 3)$, cotton root rot pathogen 


\section{Greenhouse experiments}

The tested essential oils as seed treatment exhibited a highly significant reduction in disease incidence of cotton which has been artificially infested with root rot pathogens, compared to fungicide and untreated control treatments (Table 3). Seed treatment with spearmint essential oil gave a significant reduction to emerged cotton seeds against the invasion of pathogenic fungi at the pure oil and the first two concentrations, at the pre-emergence stage. Peppermint oil at all concentrations recorded from $100 \%$ to $50 \%$ protection compared with $27.27 \%$ protection when Topsin M treatment was used, over the untreated control.

At the post-emergence stage, data also displayed that all used treatments reduced the percentage of root-rot incidence from $100 \%$ to $66.67 \%$ compared with the untreated control. The oil treated seeds had a superior impact on disease incidence by recorded plant survival percentage over cent percent $(126.9 \%$ for pure peppermint oil). Results in the existing table demonstrated that all concentrations of the tested oils caused an increase in the survival plant percentage. The spearmint oil recorded survival plant percentage ranged from $96.66 \%$ to $34.62 \%$ at the low concentration, while the peppermint oil recorded survival percentage ranged from 126.9 to $73.09 \%$. In this regard, M. phaseolina appeared further sensitivity against seed treatments through using both spearmint and peppermint oil than fungicide.

Results in the current study revealed that applying of peppermint essential oil have an observer effect on the plant growth (plant height), which differ significantly from spearmint oil.

Table 3. Incidence of cotton root rot caused by $M$. phaseolina and plant height in response to seed dressing with two essential oils (spearmint and peppermint) under greenhouse conditions.

\begin{tabular}{|c|c|c|c|c|c|c|c|c|c|c|c|}
\hline \multirow{2}{*}{$\begin{array}{l}\text { Oils \& } \\
\text { parameters }\end{array}$} & & & \multicolumn{6}{|c|}{ Oil concentrations } & \multirow{2}{*}{$\begin{array}{c}\text { Topsin } \\
\text { M }\end{array}$} & \multirow{2}{*}{\multicolumn{2}{|c|}{ control average }} \\
\hline & & & Pure & $1: 1$ & $1: 2$ & $1: 3$ & $1: 4$ & 0:1 & & & \\
\hline \multirow{5}{*}{$\begin{array}{l}\text { Pre } \\
\text { emergence } \\
\%\end{array}$} & & D I & $15.00 \mathrm{aB}$ & $18.33 \mathrm{aB}$ & $26.67 \mathrm{aAB}$ & $35.00 \mathrm{aA}$ & $38.33 \mathrm{aA}$ & $36.67 \mathrm{aA}$ & $26.67 \mathrm{aAB}$ & $36.67 \mathrm{aA}$ & $29.17 \mathrm{a}$ \\
\hline & Spearmint & $\mathrm{R} \%$ & 59.1 & 50.01 & 27.27 & 4.55 & -4.53 & 0.0 & 27.27 & & \\
\hline & & D I & $0.00 \mathrm{bD}$ & $6.67 \mathrm{bCD}$ & $13.33 \mathrm{bC}$ & $18.33 \mathrm{bBC}$ & $18.33 \mathrm{bBC}$ & $36.67 \mathrm{aA}$ & $26.67 \mathrm{aAB}$ & $36.67 \mathrm{aA}$ & $19.58 \mathrm{~b}$ \\
\hline & Peppermint & $\mathrm{R} \%$ & 100 & 81.81 & 63.65 & 50.01 & 50.01 & 0.0 & 27.27 & & \\
\hline & average & & $7.50 \mathrm{~d}$ & $12.50 \mathrm{~cd}$ & $20.00 \mathrm{bc}$ & $26.67 \mathrm{~b}$ & $28.33 \mathrm{ab}$ & $36.67 \mathrm{a}$ & $26.67 \mathrm{~b}$ & $36.67 \mathrm{a}$ & \\
\hline \multirow{5}{*}{$\begin{array}{l}\text { Post } \\
\text { emergence } \\
\%\end{array}$} & & D I & 0.00 & 3.33 & 0.00 & 3.33 & 3.33 & 16.67 & 6.67 & 20.00 & $6.67 \mathrm{a}$ \\
\hline & Spearmint & $\mathrm{R} \%$ & 100 & 83.35 & 100 & 83.35 & 83.35 & 16.65 & 66.67 & & \\
\hline & & D I & 1.67 & 0.00 & 3.33 & 3.33 & 6.67 & 16.67 & 6.67 & 20.00 & $7.29 a$ \\
\hline & Peppermint & $\mathrm{R} \%$ & 91.65 & 100 & 83.35 & 83.35 & 66.67 & 16.65 & 66.67 & & \\
\hline & average & & $0.84 \mathrm{~b}$ & $1.67 \mathrm{~b}$ & $1.67 \mathrm{~b}$ & $3.33 \mathrm{~b}$ & $5.00 \mathrm{~b}$ & $16.67 \mathrm{a}$ & $6.67 \mathrm{~b}$ & $20.00 \mathrm{a}$ & \\
\hline \multirow{5}{*}{ Stand \% } & & D I & $85.00 \mathrm{bA}$ & $78.34 \mathrm{bAB}$ & $73.33 \mathrm{bABC}$ & $61.67 \mathrm{bCD}$ & $58.34 \mathrm{bDE}$ & $46.66 \mathrm{aEF}$ & $66.66 \mathrm{aBCD}$ & $43.33 \mathrm{aF}$ & $64.16 \mathrm{~b}$ \\
\hline & jearmint & $\mathrm{E} \%$ & 96.17 & 80.78 & 69.24 & 42.33 & 34.62 & 7.69 & 53.87 & & \\
\hline & Pennermi & D I & $98.33 \mathrm{aA}$ & $93.33 \mathrm{aAB}$ & $83.33 \mathrm{aBC}$ & $78.33 \mathrm{aCD}$ & $75.00 \mathrm{aCD}$ & $46.67 \mathrm{aE}$ & $66.67 \mathrm{aD}$ & $43.33 \mathrm{aE}$ & $73.13 \mathrm{a}$ \\
\hline & Pеррегтипи & $\mathrm{E} \%$ & 126.93 & 115.39 & 92.31 & 80.78 & 73.09 & 7.69 & 53.87 & & \\
\hline & average & & $91.66 \mathrm{a}$ & $85.83 \mathrm{ab}$ & 78.33 bc & $70.00 \mathrm{~cd}$ & $66.66 \mathrm{~d}$ & $46.67 \mathrm{e}$ & $66.67 \mathrm{~d}$ & $43.33 \mathrm{e}$ & \\
\hline \multirow{5}{*}{ Plant height } & & D I & $44.50 \mathrm{bC}$ & $56.77 \mathrm{bAB}$ & $59.00 \mathrm{bAB}$ & $61.67 \mathrm{bA}$ & $57.00 \mathrm{bAB}$ & $49.33 \mathrm{aBC}$ & $50.10 \mathrm{aABC}$ & $50.67 \mathrm{aABC}$ & $53.63 \mathrm{~b}$ \\
\hline & & $\mathrm{R} \%$ & -12.18 & 12.04 & 16.44 & 21.71 & 12.49 & -2.65 & -1.13 & & \\
\hline & & D I & $84.67 \mathrm{aA}$ & $78.33 \mathrm{aA}$ & $80.60 \mathrm{aA}$ & $89.00 \mathrm{aA}$ & $81.67 \mathrm{aA}$ & $49.33 \mathrm{aB}$ & $50.10 \mathrm{aB}$ & $50.67 \mathrm{aB}$ & $70.55 \mathrm{a}$ \\
\hline & 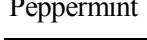 & $\mathrm{R} \%$ & 67.10 & 54.59 & 59.07 & 75.65 & 61.18 & -2.65 & -1.13 & & \\
\hline & average & & $64.58 \mathrm{~b}$ & $67.55 \mathrm{ab}$ & $69.80 \mathrm{ab}$ & $75.334 \mathrm{a}$ & $69.34 \mathrm{ab}$ & $49.33 \mathrm{c}$ & $50.10 \mathrm{c}$ & $50.67 \mathrm{c}$ & \\
\hline
\end{tabular}

The Tukey Test at a level of $5 \%$ of probability was applied

Lower case letters for columns upper case letters for rows

The averages followed by the same letter do not differ statistically between themselves

\section{DISCUSSION}

Success in controlling plant diseases has been documented from the use of artificial fungicides. It has side effects, such as possible toxicity to plants, animals, and man as well as adverse environmental impact. Fungicides can also be costly, and indiscriminate application could result in resistance, which can counteract their effectiveness. Depending on the previously mentioned constraints, alternative approaches such as using natural products applications (plant extracts and essential oils) may have a potential role in crop protection. Plant essential oils are commercially produced from numerous botanical sources. In our study, the growth inhibition and sclerotial formation of $M$. phaseolina causing root rot in cotton have been tested at various concentration of two essential oils in vitro. The obtained results showed that the mycelial growth of $M$. phaseolina isolates has been influenced differently by the two tested essential oils. The highest efficiency against M. phaseolina was registered for peppermint oil at all tested concentrations, followed by spearmint oil, with the same efficiency.
Effect of tested oils at various concentrations on sclerotial formation was noticed negatively associated with the inhibition of growth. The essential oils have the capability to penetrate and disrupt the fungal cell wall and cytoplasmic membranes, permeablise them and finally damage mitochondrial membranes. Then changes in electron flow through the electron transport system in the mitochondria damage the lipids, proteins and nucleic acid contents of the fungal cells (Arnal-Schnebelen et al., 2004). Essential oils could also reduce the membrane potential resulted into the leakage of radicals, cytochrome $\mathrm{C}$, calcium ions and proteins. Thus, permeabilization of outer and inner mitochondrial membranes leads to cell death by apoptosis and necrosis (Yoon et al., 2000). Sharma and Tripathi (2008) stated that essential oils perform on the hyphae of the mycelium, provoking the exit of constituents from the cytoplasm, the loss of rigidity of the hyphae cell wall and resulting in its collapse. The activity of essential oils not only in their capability to cross the cell wall, but also their capacity to damage cellular enzyme system, including that relating to energy 
production (Conner and Beuchat 1984). Thus, there has been grown interest in research on, natural antifungal substances utilization, which might substitute synthetic fungicides or participate to the development of new disease control agents.

In the current study, it is well confirmed the control impact of essential oils from peppermint and spearmint at different concentrations against important root rot pathogen of cotton ( $M$. phaseolina). Inhibition of the fungal growth might be due to the main components such as menthone, menthol, and limonene in peppermint essential oil in addition to carvone, 1,8 cineole, limonene, dihydro carvone, and $\beta$ - ocimene in spearmint essential oil. Furthermore, it is possible that the other minor components may act together synergistically in each oil as has previously been recommended (Moghaddam et al., 2013).

The obtained data demonstrated that use of both essential oils as seed treatment for cotton with the same or supreme anticipated output which obtained with Topsin M. Therefore, it is concluded that the tested -essential oils have potential bio-fungicides against the major root rot pathogen of cotton and as such contributed to characterize these essential oils as "broad spectrum" bio-fungicidal chemicals. Nguefack et al., (2008), concluded that essential oils from Cymbopogon citratus, Ocimum gratissimum and Thymus vulgaris, has potential bio-fungicides against the major seed-borne pathogens of rice. Helal, (2017) revealed that soaking squash seeds in biocides formulating peppermint oil leads to a significant decline of damping off and wilt diseases and caused a 10-fold increase in the plants survival which grown in non-infested soil, compared with the non-treated plants. In our study, the obtained results showed that peppermint and spearmint essential oils have an inhibiting impact on the pathogens growth of cotton root rot in vitro, and their efficacy is prolonged to protect seed germination or plant invasion in vivo test.

In the present study, M. phaseolina revealed more sensitivity against seed treatments by applying peppermint oil than treatments by spearmint oil and Topsin M. The application of peppermint oil leads to a significant reduction of damping- off diseases and induced an increase in the survival of the plants compared with the non-treated plants. The present observation displayed that increasing essential oils concentration led to a significant decline in disease incidence.

\section{CONCLUSION}

The results of this study have shown that volatile oil from $M$. piperita has strong remarkable antifungal activity against $M$. phaseolina than $M$. viridis. Gas Chromatographic analysis of volatile oil from $M$. viridis was determined, and its main component was carvone. While the main component of mentha piperita was menthone. The study results can be used in the management of plant pathogenic fungi.

\section{REFERENCES}

Arnal-Schnebelen, B.; F. Hadji-Minaglou; J. F. Peroteau; F Ribeyre and V.G. de Billerbeck (2004). Essential oils in infectious gynaecological disease: a statistical study of 658 cases. Int. J. Aromatherapy. 14(4): 192-197.
Arya, P.; Godara, S.L.; Bimla and A. Jat.(2017). Efficacy of antagonists against Macrophomina phaseolina inciting dry root rot disease of groundnut. $\mathrm{J}$. Pharmaco.\& Phytochem. 6(6): 1171-1173.

Aslam, A.; Naz, F.; Arshad, M.; Qureshi, R. and C. A.Rauf, (2010). In Vitro antifungal activity of selected medicinal plant diffusates against Alternaria solani, Rhizoctonia solani and Macrophomina phaseolina. Pak. J. Bot., 42: 29112919.

Baser, K., (1993).Volatile oils of Anatolian Labiatae: a profile. Acta Hort., 333:217-238.

Bowers, J.H. and L.C. Locke, (2000) Effect of botanical extracts on the population density of Fusarium oxisporum in soil and control of Fusarium wilt in the green house. Plant Dis., 84: 300-305.

Boyraz , N. and M. Ozcan ( 2006). Inhibition of phytopathogenic fungi by essential oil, hydrosol, ground material and extract of summer savory (Satureja hortensis L.) growing wild in Turkey. Intern J. Food Micro., 107:238-242.

Conner, D.E. and L. M. Beuchat, (1984). Effect of essential oils from plants on growth of food spoilage. yeasts. J. Food Sci., 49: 429-434.

Dhifi, W.; Litaiem, M.; Jelali, N.; Hamdi, N. and W. Mnif (2011). Identification of a new chemotype of the plant Mentha aquatica grown in Tunisia: Tunisian folkloric medicine. World J . Microbiol \& Biotechnol., 25 (12) :2227-2238.

El-Shoraky, F. S.(2016). Efficacy of some essential oils applied as seed treatment for control seedling diseases of cotton. Egy. J. Plant Por. Res., 4(4):2143.

El-Shoraky, F. S. and N. M. M. Rashed (2012). Antimicrobial and pesticidal potentiality of essential oils of some medicinal plants against deterioration of cumin seeds. J. Plant Prot. \& Path., Mans. Univ., 3 (12): 1253 - 1268.

Gujar, J. and D. Talwankar, (2012). Antifungal potential of crude plant extract on some pathogenic fungi. World J. Sci.\& Techno., 2: 58-62.

Hadizadeh, I.; Peivastegan, B. and M. Kolahi, (2009). Antifungal activity of nettle (Urticad ioica L.), colocynth (Citrullus colocynthis L. Schrad), oleander (Nerium oleander L.) and konar (Ziziphus spina-christi L.) extracts on plants pathogenic fungi. Pak. J. Bio. Sci., 12: 58-63.

Helal, I. M. (2017). Control of damping-off disease in some plants using environmentally safe biocides. Pak. J. Bot., 49(1): 361-370.

Helal, I.M.M. and M.H. Abdeldaiem. (2009). Inhibition of green and blue rots in orange fruits by using clove and thyme essential oils treated by gamma radiation. Arab J. Nucl. Sci. \& App., 42: 257-268.

Isman, M.B. and C.M. Machial (2006) Pesticides based on plant essential oils: from traditional practice to commercialization. In M. Rai and M.C. Carpinella (eds.), Naturally Occurring Bioactive Compounds, Elsevier, BV, pp 29-44. 
Jirovetz, L.; Wlcek, K.; Buchbauer, G.; Gochev, V.; Girova, T.; Dobreva, A.; Stoyanova, A. and E. Schmidt (2007). Chemical composition and antifungal activity of essential oils from various Bulgarian Mentha $\times$ piperita L. cultivars against clinical isolates of Candida albicans. J. Essent. Oil Bearing Plants., 10(5): 412-420.

Khan, S. N. (2007). Macrophomina phaseolina as causal agent for charcoal rot of sunflower. Mycopath., 5(2): 111-118.

Kim, D. I.; Park, J. D.; Kim, S. G; Kuk, H.; Jang, M. J. and S. S. Kim (2005). Screening of some crude plant extracts for their acaricidal and insecticidal efficacies. J. Asia-Pacific Entom. 8: 93-100.

Loo, Y.H., Shell, P.S. and H.H. Thornberry (1945). Assay of streptomycin by the paper disc plate method. J. Bacteriol. 50(6):701-709.

Mario, D.; Giovanni, S.; Stefania, D. and B. Emanuela (2002). Essential oil formulations useful as a new tool for insect pest control. Pharm. Sci. Tech. 3: 13.

Mkaddem, M.; Bouajila, J.; Ennajar, M.; Lebrihi, A.; Mathieu, F. and M. Romdhane (2009).Chemical composition and antimicrobial and antioxidant activities of Mentha (longifolia L. and viridis) essential oils. J. Food Sci., 74 (7):358-363.

Moghaddam, M.; Pourbaige, M.; Tabar, H.K.; Farhadi, N. and S. M. A. Hosseini (2013).Composition and antifungal activity of peppermint (Mentha piperita) essential oil from Iran. J. Essent. Oil-Bearing Plants. 16(4):506-512.

Muller, R.F.; Berger, B. and O. Yegen (1995). Chemical composition and fungi toxic properties to phyto pathogenic fungi of essential oils of selected aromatic plants growing wild in Turkey. J. Agric. Food Chem., 43: 2262-2266.

Neerman M. F. (2003). Sesquiterpenes lactones a diverse class of compounds found in essential oils possessing antibacterial and antifungal properties. Int. J. Aromatic., 13:114-120.
Nguefack, J.; Leth, V.; Lekagne Dongmo, J.B.; Torp, J.; Zollo, P. H. A. and S. Nyasse (2008). Use of three essential oils as seed treatments against seed-borne fungi of rice (Oryza sativa L.). American-Eurasian J. Agric. \& Environ. Sci., 4 (5): 554-560.

Parmar, H.V.; Kapadia, H.J. and C. M. Bhaliya (2017). Efficacy of different fungicides against Macrophomina phaseolina (Tassi) Goid causing castor root rot. Int. J. Chemical Studies. 5(5): 18071809

Sharma, N. and A. Tripathi (2008). Effects of Citrus sinensis (L.) Osbeck epicarp essential oil on growth and morphogenesis of Aspergillus niger Van Tieghem. Microb. Res., 163 (3): 337 - 344.

Silva, F. de A. S. e. \& Azevedo, C. A. V. de.( 2009) Principal Components Analysis in the Software Assistat-Statistical Attendance. In: world congress on computers in agriculture, 7, Reno-NV-USA: American Society of Agricultural and Biological Engineers.

Singh, J.; Dubeyd, A.K. and N. N. Tripathi (1994). Antifungal Activity of Mentha spicata. Int. J. Pharmacogn., 32 (4):314-319.

Su, G.; Suh, S. O.; Schneider, R. W. and J. S. Russin (2001). Host specialization in the charcoal rot fungus, Macrophomina phaseolina. Phytopathology. 91:120-126.

Viuda-Martos M.; Ruiz-Navajas Y.; Fernandez-Lopez J. and J.A. Perez- -Alvarez (2007). Antifungal activities of thyme, clove and oregano essential oils. J. Food Safety, 27 (1): 91-101.

Yoon, H.S.; Moon, S.C.; Kim, N.D.; Park, B.S.; Jeong, M.H. and Y.H, Yoo ( 2000). Genistein induces apoptosis of RPE-J cells by opening mitochondrial PTP. Biochem. Biophys. Res. Commun. 276(1): 151-156.

Zambonelli, A.; Aulerjo, A.Z.D.; Bianchi, A. and A. Albasini (1996). Effects of essential oils on phytopathogenic fungi in vitro. J. Phytopathology. 94: 491-495.

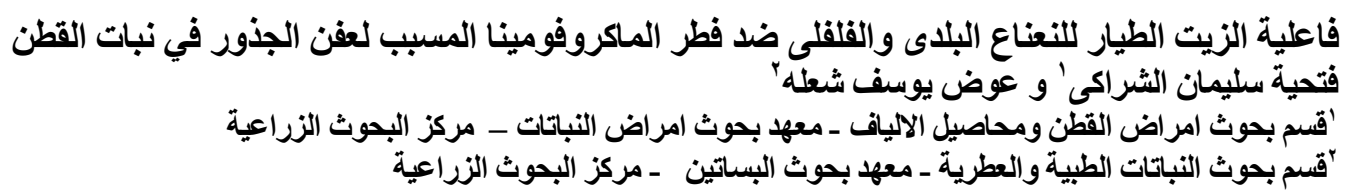

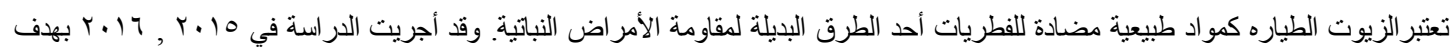

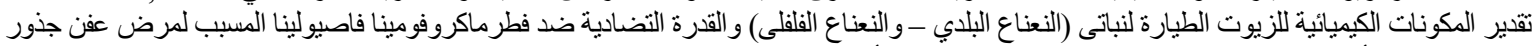

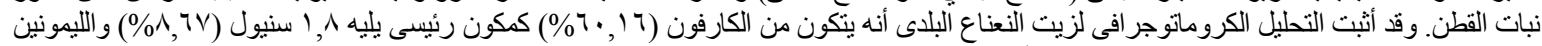

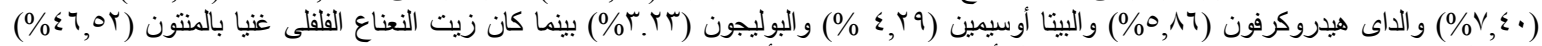

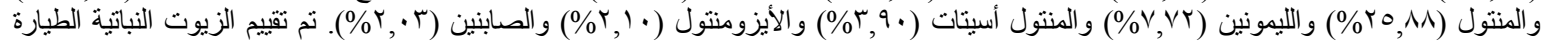

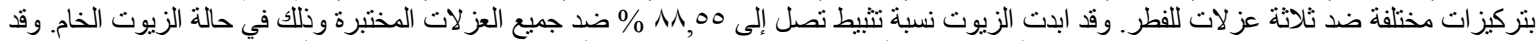

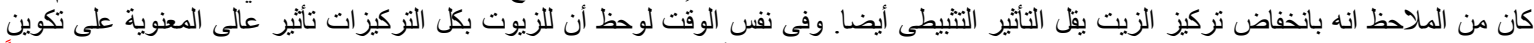

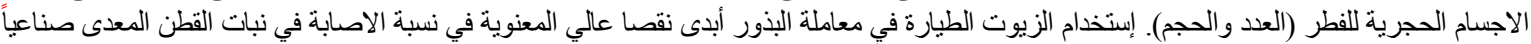

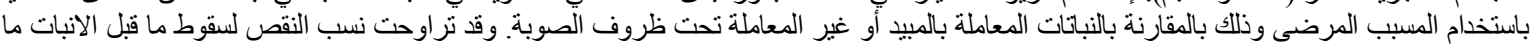

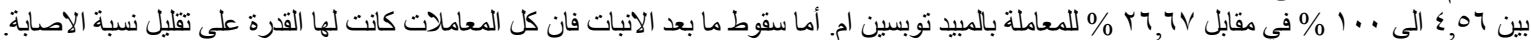

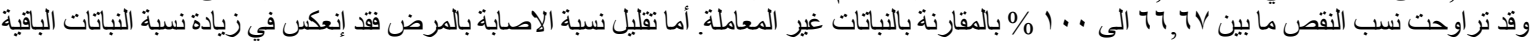

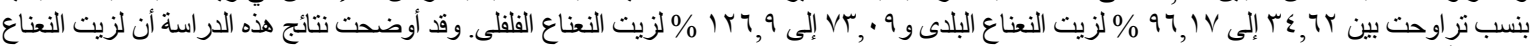

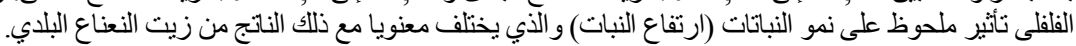

